\title{
Citation Classics and Trends in the Field of Opioids: A Bibliometric Analysis
}

\author{
Hira F. Akbar ${ }^{1}$, Khadijah Siddiq $^{2}$, Salman Nusrat ${ }^{3}$ \\ 1. Internal Medicine, Dow Medical College, Dow University of Health Sciences, Karachi, PAK 2. Internal \\ Medicine, Civil Hospital Karachi, Dow University of Health Sciences, Karachi, PAK 3. Gasteroenterology, \\ University of Oklahoma Health Sciences Center, Oklahoma City, USA
}

Corresponding author: Hira F. Akbar, hira.feroz@gmail.com

\section{Abstract}

\section{Introduction}

Bibliometric analysis is one of the emerging and latest statistical study type used to examine and keep a systemic record of the research done on a particular topic of a certain field. A number of such bibliometric studies are conducted on various topics of the medical science but none existed on the vast topic of pharmacology - opioids. Hence, we present a bibliometric analysis of the 'Citation Classics' of opioids.

\section{Method}

The primary database chosen to extract the citation classics of opioids was Scopus. Top 100 citation classics were arranged according to the citation count and then analyzed.

\section{Results}

The top 100 citation classics were published between 1957 and 2013, among which seventy-two were published from 1977 to 1997. Among all nineteen countries that contributed to these citation classics, United States of America alone produced sixty-three classics. The top three journals of the list were multidisciplinary and contained 36 citation classics. Endogenous opioids were the most studied $(n=35)$ class of opioids among the citation classes and the most studied subject was of the neurosciences.

\section{Conclusion}

The subject areas of neurology and analgesic aspects of opioids are well established and endogenous and synthetic opioids were the most studied classes of opioids. However, the egregious issues of addiction and misuse of opioids were underrepresented in the citation

Received 08/08/2018 Review began 08/25/2018 Review ended 06/20/2019 Published 07/01/2019

\section{(C) Copyright 2019}

Akbar et al. This is an open access article distributed under the terms of the Creative Commons Attribution License CC-BY 3.0., which permits unrestricted use, distribution, and reproduction in any medium, provided the original author and source are credited. classics. The pulmonary and gastrointestinal aspects of opioids are also marginalized among the citation classics.

Categories: Anesthesiology, Neurology, Pain Management

Keywords: citation classics, opioids, bibliometric analysis, scopus, citescore

\section{Introduction}

Each year, extensive contributions are made to the medical science literature [1]. Bibliometric research provides quantitative analysis and extensive insight regarding the research conducted, the era in which the work is performed, and eminent authors, countries, and institutions; this 
approach also identifies aspects that remain to be examined [2], hence to monitor studies regarding a specific topic, practitioners refer to bibliometric researches. Although several bibliometric studies have been conducted in breast cancer [3], orthopedic surgery [4], epilepsy [5], thrombolytic therapy [6], and valvular heart diseases [7], our literature search revealed no such bibliometric analysis for opioids.

Opioids are the prototypical derivatives of opium, which is considered one of the world's oldest drugs [8]. Opioids are extensively used as analgesics, antitussive agents, antidiarrheal drugs, and anesthetic agents for management of acute pulmonary edema and various other treatments [9]. Some opioids, such as heroin, are illegal [10]. Moreover, the abuse or overuse of opioids can result in adverse effects and opioid dependence [11].

To fill this gap, we conducted a bibliometric analysis on opioids. The paper presents the opioid citation classics, that is, articles that were cited more than 400 times [12], as well as the trends in recently published articles.

\section{Materials And Methods}

A citation search was conducted to identify the 100 most cited articles and citation classics in the available literature (see Appendix). Like other researchers [6,7], we chose Elsevier's Scopus online database for our search, as Scopus provides $20 \%$ more coverage than Web of Science with more accurate citation counts than Google Scholar [13]. Full articles were accessed from PubMed, EMBASE (Excerpta Medica dataBASE), and Science Direct.

'Opioids', 'opiates', and 'opium' were our primary search keywords. To avoid bias and prevent missing relevant articles, we expanded our list to the names of individual opioids mentioned in Basic and Clinical Pharmacology [14]. The extended list included 'buprenorphine', 'butorphanol', 'codeine', 'diphenoxylate', 'fentanyl', 'heroin', 'levorphanol', 'loperamide' 'methadone', 'meperidine', 'morphine', 'naloxone', 'nalbuphine', 'nalmefene', 'naltrexone', 'oxycodone', 'propoxyphene', 'pentazocine', 'tramadol', and 'tapentadol'. All electronic database searches were performed on October 9th, 2017. Keywords were searched in 'article titles', 'abstracts', and 'keywords'. Relevant articles were retrieved and sorted by the option of 'Cited by', which yielded a list of articles arranged in descending order of their number of citations. No filters of language, time, human studies, subject area, territory, or affiliations were used. Abstracts and full texts of the articles were read from the sorted list and irrelevant articles were excluded from the analysis.

All article types, other than those requiring manual searching, telephone access, guidelines, and non-PubMed indexed articles, were included. The dataset was further evaluated by title, first and senior author, institution, department of the first author, topic, source, year of publication, and country of origin. In contrast with other researchers [6,7], we used CiteScore [15], Source Normalized Impact per Paper (SNIP), and SCImago Journal Rank (SJR) to rank the journals. Some articles were cited more frequently than others, due to differences in the time since publication. We adjusted for this error by determining citation index for each article.

Citation analysis of the extracted articles was conducted both by using Scopus and by manually screening the articles. Articles were further classified into two broad categories: 1) major subject area and 2) class of opioids. Tables and charts were created using Microsoft Excel 2016 (Microsoft Corporation, Washington, US). IBM Statistical Package for the Social Sciences (IBM SPSS Statistics for Windows, Version 20.0. Armonk, New York, US) was used to apply the Pearson product moment correlation co-efficient to evaluate the relationship between citation times, CiteScore, and citation density. Chi-square test was applied to observe significant difference between the categorical values and Non-parametric tests, such as the Mann-Whitney $\mathrm{U}$ test and Kruskal-Wallis test, were applied to evaluate any significant difference between 


\section{Cureus}

categorical and numerical data. P-value $<0.05$ was considered significant in all cases.

\section{Results}

\section{Trends of citation classics}

Top citation classics were published from 1957 to 2013. Most were original articles ( $\mathrm{n}=80)$, while the remainder were review articles $(n=17)$, conference papers $(n=1)$, and letters to the editor $(\mathrm{n}=2)$. The citations of those articles summed to 92,413, ranging from 545 to 3,149, with a median of 762.5 and a mean of 924.13 . Approximately $4 \%$ were self-cited and $3.6 \%$ were book citations, reducing the original citations to 85,482. Citation density (citations per year) ranged from 10.53 to 147.63 , with a median of 33.06 and a mean of 38.97. A moderately positive correlation was found between citation count and citation density ( $\mathrm{r}=0.511)$, while no significant correlation was found between citation count and year of publication. There was no significant difference between the citations of original articles and other article types $(\mathrm{p}=$ 0.311). Figure 1 shows the overall trend of total citations by year, with the peak citations in 1988.

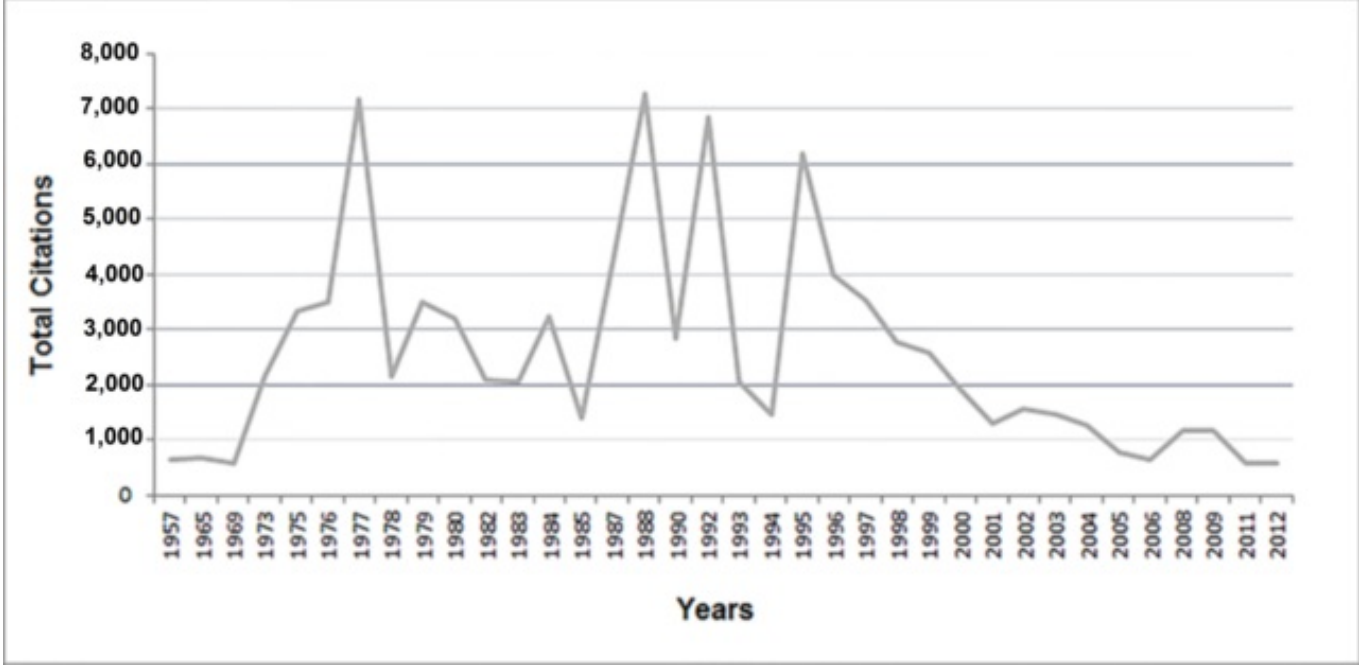

FIGURE 1: Total citations per year.

\section{Origins, institutions and authorships}

The citation classics were produced by nineteen different countries. Figure 2 shows major contributors to the top 100 citation classics, with the leading contribution from the United States $(n=58)$. 


\section{Cureus}

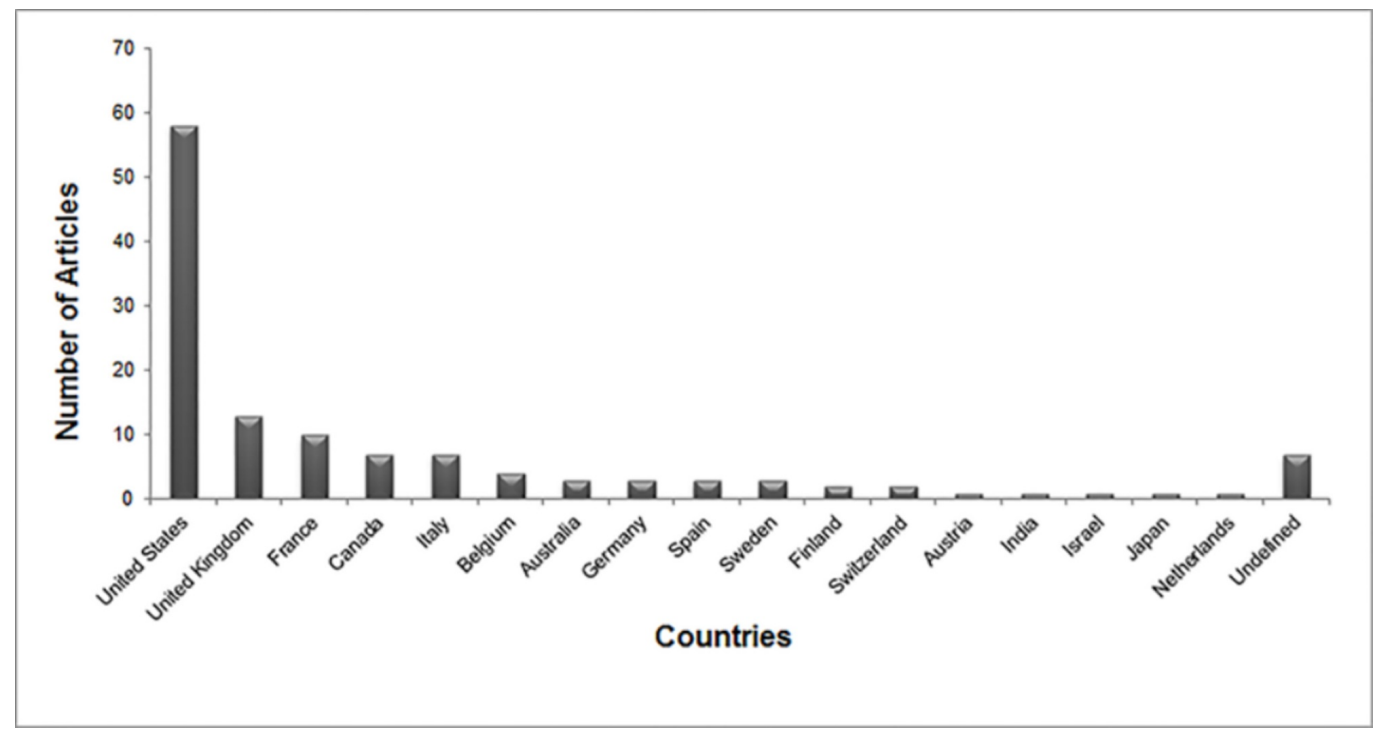

FIGURE 2: Articles originating from each country.

In addition, 160 different institutions contributed to the top cited articles list, with almost 40 institutions having two or more articles in the list. The University of Michigan ( $\mathrm{n}=15)$ and VA Medical Center $(\mathrm{n}=7)$ had the most citation classics of all institutions on the list. The third most-cited institution, University of Cagliari $(n=5)$, is in Italy.

Five hundred authors contributed to the citation classics, with a median of four authors and mean of five authors. The number of authors per article ranged from 1 to 21. Details of authors with more than two citation classics are shown in Table 1.

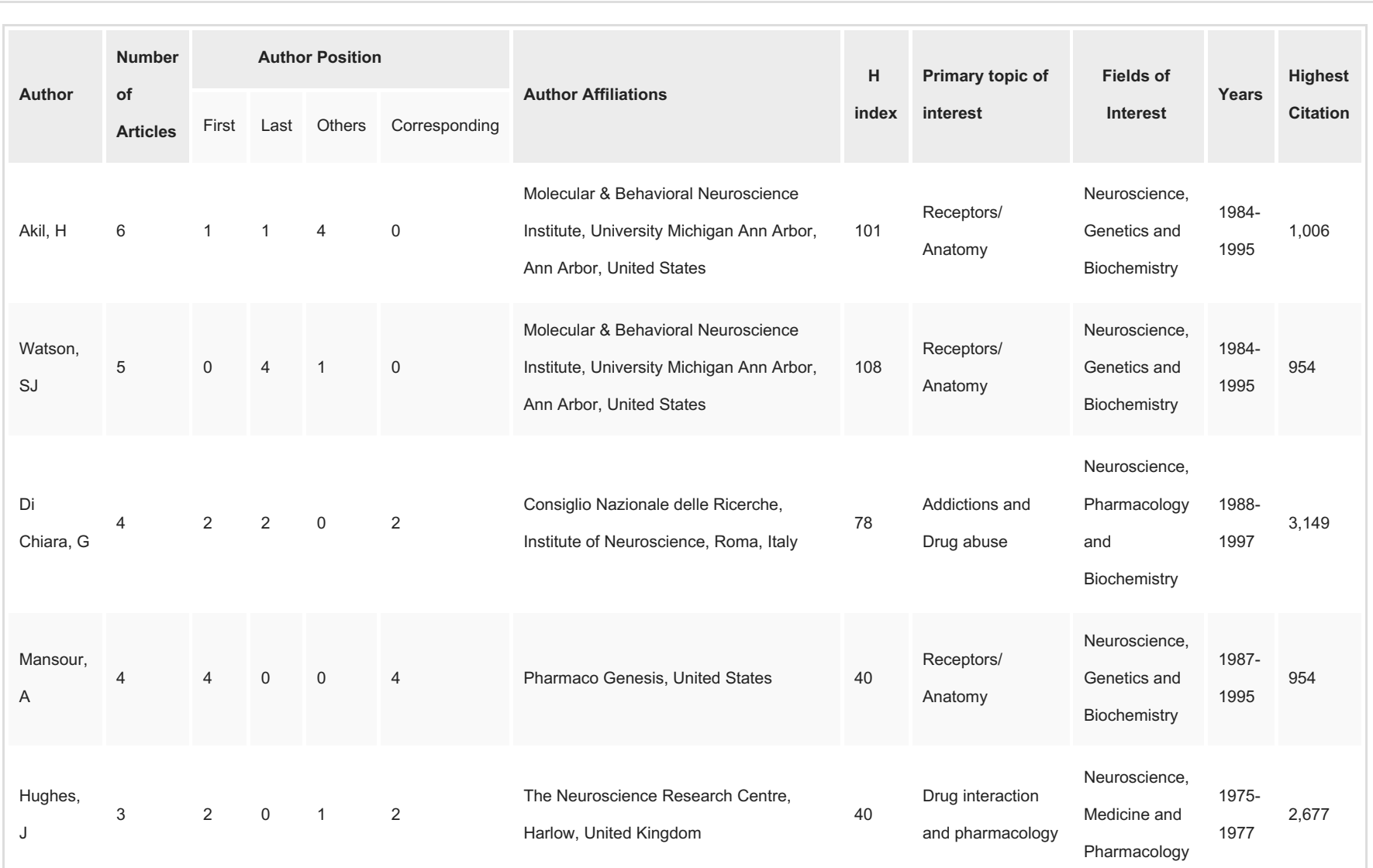




\section{Cureus}

\begin{tabular}{|c|c|c|c|c|c|c|c|c|c|c|c|}
\hline $\begin{array}{l}\text { Imperato, } \\
\text { A }\end{array}$ & 3 & 0 & 2 & 1 & 0 & $\begin{array}{l}\text { Sanofi S.A., Neurodegenerative Disease } \\
\text { Program, Gentilly, France }\end{array}$ & 44 & $\begin{array}{l}\text { Addictions and } \\
\text { Drug abuse Drug } \\
\text { interaction and } \\
\text { pharmacology }\end{array}$ & $\begin{array}{l}\text { Neuroscience, } \\
\text { Genetics and } \\
\text { Biochemistry }\end{array}$ & $\begin{array}{l}1988- \\
1999\end{array}$ & 3,149 \\
\hline Kalso, E & 3 & 1 & 0 & 2 & 0 & $\begin{array}{l}\text { Helsinki University Central Hospital, } \\
\text { Intensive Care and Pain Medicine, } \\
\text { Helsinki, Finland }\end{array}$ & 64 & Pain Management & $\begin{array}{l}\text { Neuroscience, } \\
\text { Medicine and } \\
\text { Pharmacology }\end{array}$ & $\begin{array}{l}2001- \\
2004\end{array}$ & 969 \\
\hline $\begin{array}{l}\text { Kosterlitz, } \\
\text { HW }\end{array}$ & 3 & 0 & 2 & 1 & 0 & $\begin{array}{l}\text { University of Aberdeen, Aberdeen, United } \\
\text { Kingdom }\end{array}$ & 101 & $\begin{array}{l}\text { Receptors/ } \\
\text { Anatomy, } \\
\text { Pharmacology }\end{array}$ & $\begin{array}{l}\text { Pharmacology, } \\
\text { Biochemistry } \\
\text { and Genetics }\end{array}$ & $\begin{array}{l}1975- \\
1983\end{array}$ & 2,677 \\
\hline Ling, $\mathrm{N}$ & 3 & 0 & 1 & 2 & 0 & $\begin{array}{l}\text { Neurocrine Bioscience, Department of } \\
\text { Peptide Chemistry, San Diego, United } \\
\text { States }\end{array}$ & 96 & $\begin{array}{l}\text { Pharmacology } \\
\text { and endorphins }\end{array}$ & $\begin{array}{l}\text { Neuroscience, } \\
\text { Medicine and } \\
\text { Biochemistry }\end{array}$ & $\begin{array}{l}1976- \\
1977\end{array}$ & 1,101 \\
\hline $\begin{array}{l}\text { Roques, } \\
\text { BP }\end{array}$ & 3 & 1 & 0 & 2 & 1 & Pharmaleads, Paris, France & 82 & $\begin{array}{l}\text { Pharmacology } \\
\text { and opiums }\end{array}$ & $\begin{array}{l}\text { Neuroscience, } \\
\text { Pharmacology } \\
\text { and } \\
\text { Biochemistry }\end{array}$ & $\begin{array}{l}1980- \\
1999\end{array}$ & 1,139 \\
\hline $\begin{array}{l}\text { Vassart, } \\
\text { G }\end{array}$ & 3 & 0 & 0 & 3 & 0 & $\begin{array}{l}\text { Université libre de Bruxelles (ULB), } \\
\text { Institut de Recherche Interdisciplinaire en } \\
\text { Biologie Humaine et Moléculaire } \\
\text { (IRIBHM), Brussels, Belgium }\end{array}$ & 90 & $\begin{array}{l}\text { Receptors/ } \\
\text { Anatomy }\end{array}$ & $\begin{array}{l}\text { Biochemsitry, } \\
\text { Medicine and } \\
\text { Pharmacology }\end{array}$ & $\begin{array}{l}1994- \\
1999\end{array}$ & 1,636 \\
\hline Bloom, F & 3 & 1 & 2 & 0 & 1 & $\begin{array}{l}\text { Scripps Research Institute, San Diego, } \\
\text { United States }\end{array}$ & 117 & $\begin{array}{l}\text { Pharmacology } \\
\text { and endorphins }\end{array}$ & $\begin{array}{l}\text { Neuroscience, } \\
\text { Genetics and } \\
\text { Biochemistry }\end{array}$ & $\begin{array}{l}1976- \\
1988\end{array}$ & 1,606 \\
\hline
\end{tabular}

TABLE 1: Authors with more than two articles in the top 100.

\section{Journals}

The citation classics were published in 40 journals. The CiteScore of these journals ranged from 2.45 to 29.6, with a median of 8.67 and a mode of 7.87. More than half of the articles $(n=62)$ were published in nine journals (Table 2). Weak positive correlations were found between CiteScores of the journals and the number of articles published $(\mathrm{r}=0.255)$, total citations of the journals ( $\mathrm{r}=0.253)$, citation count of the articles $(\mathrm{r}=0.080)$, citation density $(\mathrm{r}=0.085)$, and years of publication $(\mathrm{r}=0.086)$. There was no significant difference between CiteScore by subject area $(\mathrm{p}=0.432)$, classification of opioids $(\mathrm{p}=0.076)$, or type of article $(\mathrm{p}=0.267)$. 


\section{Cureus}

\begin{tabular}{|c|c|c|c|c|c|c|c|c|c|c|}
\hline SOURCE TITLE & $\begin{array}{l}\text { Number } \\
\text { of } \\
\text { Articles }\end{array}$ & CiteScore & $\begin{array}{l}\text { Highest } \\
\text { CiteScore } \\
\text { Percentile }\end{array}$ & SNIP $\mathbf{P}^{\ddagger}$ & SJR & $\begin{array}{l}\% \\
\text { review }\end{array}$ & $\%$ cited & $\begin{array}{l}\text { Total } \\
\text { citations }\end{array}$ & $\begin{array}{l}\text { CiteScore } \\
\text { Rank }\end{array}$ & Subject Area \\
\hline Science & 14 & 14.39 & 99th & 13.53 & 7.68 & 10.83 & 34.83 & 13,914 & $1 / 77$ & Multidisciplinary \\
\hline Nature & 12 & 13.33 & 98th & 8.04 & 18.13 & 2.02 & 42.97 & 12,720 & $2 / 77$ & Multidisciplinary \\
\hline $\begin{array}{l}\text { Proceedings Of The National } \\
\text { Academy Of Sciences Of The } \\
\text { United States Of America }\end{array}$ & 10 & 8.56 & 96th & 2.63 & 6.32 & 1.16 & 15.76 & 9,883 & $3 / 77$ & Multidisciplinary \\
\hline Anesthesiology & 6 & 3.01 & 91st & 2.27 & 2.12 & 7.88 & 51.45 & 4,373 & $2 / 23$ & $\begin{array}{l}\text { Anesthesiology } \\
\text { and Pain } \\
\text { medicine }\end{array}$ \\
\hline Pain & 5 & 4.58 & 97th & 1.94 & 2.84 & 8.09 & 27.75 & 5,437 & 3/115 & $\begin{array}{l}\text { Anesthesiology } \\
\text { and Pain } \\
\text { medicine }\end{array}$ \\
\hline $\begin{array}{l}\text { Journal Of Pharmacology And } \\
\text { Experimental Therapeutics }\end{array}$ & 4 & 3.9 & 85th & 1.16 & 1.76 & 3.54 & 19.52 & 4,689 & $43 / 299$ & $\begin{array}{l}\text { Pharmacology, } \\
\text { Toxicology and } \\
\text { Pharmaceutics }\end{array}$ \\
\hline $\begin{array}{l}\text { JAMA Journal of American Medical } \\
\text { Association }\end{array}$ & 4 & 6.67 & 98th & 9.16 & 6.86 & & $48 \%$ & 3,557 & 23/2156 & Medicine \\
\hline New England Journal Of Medicine & 4 & 12.82 & 99th & 14.68 & 15.76 & 10.12 & 54.74 & 3,850 & $7 / 2156$ & Medicine \\
\hline Brain Research & 3 & 2.75 & 78th & 0.82 & 1.26 & 19.53 & 29.61 & 1,942 & 69/322 & Neurology \\
\hline
\end{tabular}

TABLE 2: Journals with more than two articles in the top 100.

${ }^{\ddagger}$ SNIP: Source Normalized Impact per Paper.

${ }^{z}$ SJR: SCImago Journal Rank

\section{Subject areas and topical distribution}

Citation classics belonged to four major subject areas: neurosciences, anesthesiology and pain management, gastroenterology, and general medicine. Figure 3 shows the number of articles published each year by specific subject area. The distribution of citation count was same in all subject areas $(\mathrm{p}=0.260)$. No significant difference was found between subject areas and citation density $(p=0.136)$ and year of publication $(p=0.105)$. 


\section{Cureus}

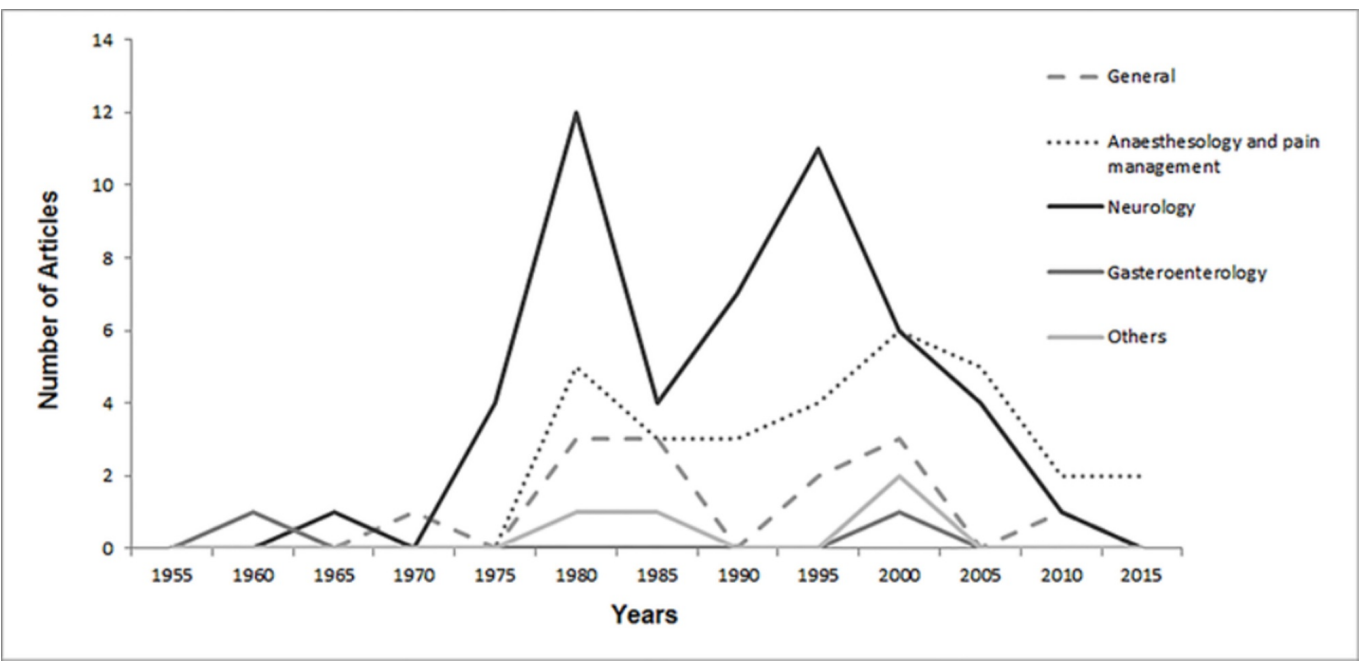

FIGURE 3: Number of articles published each year per major subject area.

Forty-six of the citation classics primarily discussed opioids' mechanism of action, followed by adverse effects $(n=24)$, clinical uses $(n=13)$, pharmacokinetics $(n=4)$, basic sciences $(n=3)$, and opioid tolerance $(n=2)$. The remaining seven discussed various other topics.

\section{Classes of opioids}

Citation classics were distributed among four major opioid classes and a miscellaneous topics category. Thirty-five articles discussed endogenous opioids, followed by synthetic opioids $(\mathrm{n}=30)$, opium $(\mathrm{n}=8)$, and semi-synthetic opioids $(\mathrm{n}=4)$. The remaining 23 citation classics discussed opioids in general. Significant differences were observed between classes of opioids and years of publication ( $\mathrm{p}=0.037)$, citation count $(\mathrm{p}=0.000)$, and citation density $(\mathrm{p}=0.000)$. Figure 4 shows the number of articles on classification of opioids published in each subject area. There was no significant difference between articles published on different classes of opioids and subject areas $(\mathrm{p}=0.491)$.

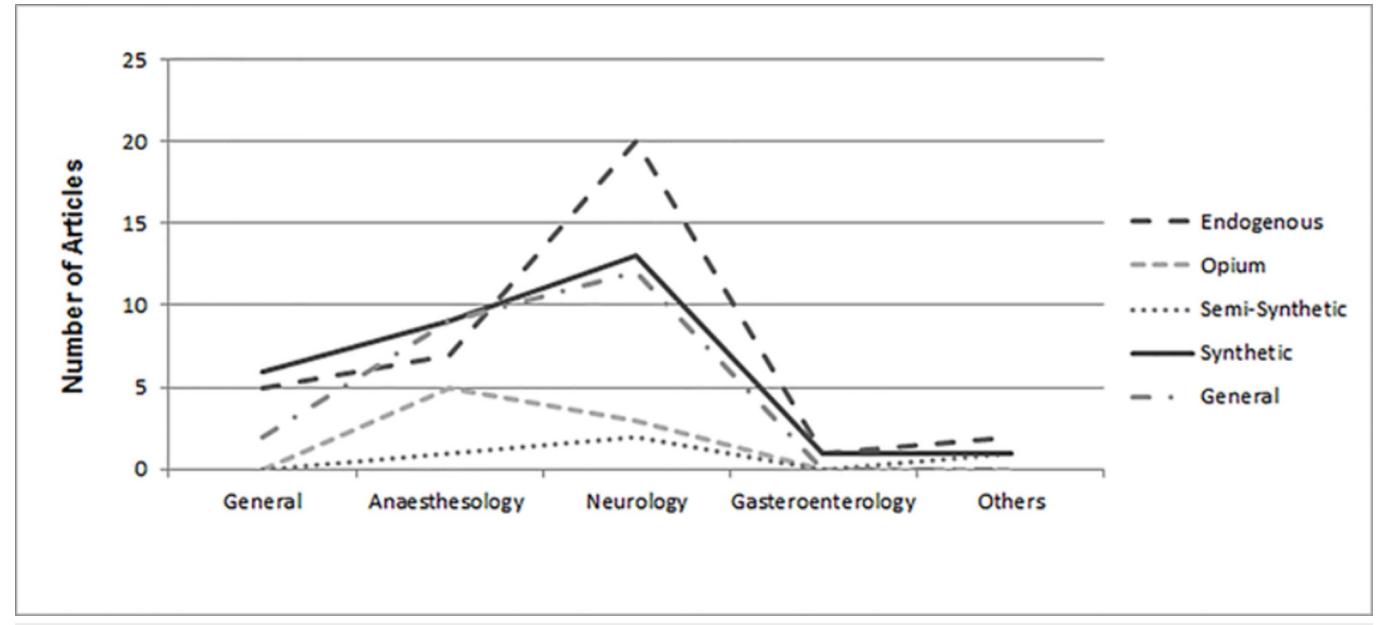

FIGURE 4: Number of articles on classification of opioids published in each subject area. 


\section{Discussion}

The use of Opium dates back to the commencement of the Greek era [16]; opioids are opium derivatives [17]. The oldest opioid articles available on PubMed were published in 1945. The fact that none of these pioneer articles is a citation classic suggests that the quality of the work plays a greater role in citation number than does the number of years for which the article has been a part of the literature [12].

\section{Trends of citation classics}

Citation classics ranged over 53 years of publication, with zero to seven articles per year. Seventy-two of the citation classics were published from 1977 to 1997. The most-often cited article in the list was published in 1988. In contrast with previous studies [7], our graph of the total article citations over time (Figure 1) showed several peaks and troughs. After 1995, a gradual decrease in citations occurred, followed by a rapid decrease in 1997. Only 24 of all articles published after 1997 were citation classics. This finding supports the idea that some topics undergo intense study at certain times during which extensive research is performed, and after which the topic ceases to be of broad and current interest [18]. There was no significant difference between the citations of original research articles and review articles $(p=0.310)$, contradicting the belief that review articles are more often cited [7]. Interestingly, only two articles had a citation density greater than one hundred, and the article ranked seventeenth had the highest citation density of 147.63 by Chou R et al.

\section{Origins, institutions and authorships}

Sixty-three of the citation classics came from the United States (Figure 1). Campbell explains this major contribution from the USA by stating that reviewers and authors from the USA show bias towards local papers [19]. The United Kingdom produced the second-highest number of citation classics $(n=13)$, followed by France $(n=10)$. Thirteen of the citation classics were produced through the contributions of researchers in multiple countries.

In total, 160 institutions contributed to our citation classics. Forty institutions had more than two articles among the citation classics. Thirty-five of the citation classics had multiinstitutional origins. Of these, 13 papers were also multinational, suggesting that international collaborations produce high-quality output that greatly benefits the scientific community [7].

A total of 500 authors contributed to the citation classics. Each of the top 12 authors contributed to at least three articles. Bloom F, although 12th in rank, had the highest H-index, followed by Watson SJ, Kosterlitz HW, and Akil H. Authors with a high H-index not only have a greater chance of having their work accepted, but are also more likely to get promotions and become reviewers [20].

\section{Journals}

As the results indicated, the citation classics were published in 40 journals. The top three journals were multidisciplinary and contained 36 citation classics. Sixteen were neurosciencesbased journals with 23 citation classics. Seven were medicine journals with 13 citation classics. Similarly, pharmacology-based journals $(n=7)$ had 12 citation classics, and anesthesiology journals had 11 citation classics. Among the multidisciplinary journals, Science had the highest CiteScore of 14.39 and the highest number of citation classics. Both top CiteScore journals had only one article each in the top hundred. Among the neuroscience-based journals, Annual Review of Neuroscience had the highest CiteScore of 16.43, followed by Trends in Neurosciences, with the CiteScore of 10.37. The top citation classic was published in Proceedings of the National Academy of Sciences of the United States of America, a multidisciplinary journal with a CiteScore of 8.56. This journal had ten articles in the list of 
citation classics (Table 2). Physiological Reviews, a medicine-based journal, had the highest CiteScore (29.60) overall, but only one citation classic was published in it.

According to the Bradford law, our top three multidisciplinary journals that had the highest citations are Zone 1 or core journals [21]. Similarly, the journals belonging to the categories of neurosciences and medicine are Zone 2 and Zone 3 journals, respectively. This trend indicates that although opioids are part of the field of pharmacology, citation classics on opioids were primarily published in multidisciplinary and neurology-based journals, which contradicts an established concept that highly cited articles are published in field-specific journals [13]. We used multiple analytical parameters to rank our journals, including CiteScore, SJR, and SNIP, to reduce bias [22]. CiteScore is a metric similar to a journal's Impact Factor that gives us a comprehensive view of the journal's effect on the scientific community.

\section{Subject area and topical distribution}

Neurosciences seemed to be the most studied subject area, as half of the citation classics covered topics in neurology, psychology, cognitive sciences, and psychiatry. This finding is similar to previous reports [23]. The most likely explanation is that the mechanism of action, clinical uses, tolerance, and addiction involve the neural system. Thirty-one of the citation classics addressed anaesthesiology and pain management, demonstrating the major role of opioids in this subject area. Even though opioids have major effects on the gastrointestinal tract [24], we observed that gastroenterology articles were underrepresented among the opioid citation classics. The work in various subject areas was uniformly distributed among years of publication.

As mentioned above, citation classics primarily discussed the opioid mechanism of action, covering the structure, saturation, availability, binding sites, and location of opioid receptors in various organs. Although deaths due to opioid overuse and addiction continue to skyrocket [25], 24 articles focused on the adverse effects of opioids. In these articles, drug dependence, abuse, and addiction were highlighted. Only one article among the citation classics examined prescription protocols.

\section{Classes of opioids}

Opioids are classified as endogenous, opium alkaloids, synthetic opioids, and semi-synthetic opioids [16]. Endogenous opioids, which include endorphins, enkephalins, and dynorphins, were most-studied. Twenty of the 35 citation classics regarding endogenous opioids fell under the subject area of neurology (Figure 4). The second most cited class was synthetic opioids. Thirteen of these 30 citation classics fell under the subject area of neurology.

Some limitations must be considered. Possible citation bias, including in-house citations, negative citations, and incomplete citations is a major limitation. In addition, the use of one database to extract the list may have overlooked articles that were not recognized by Scopus, and excluded textbooks. Scopus has been reported to miss older citations, which results in omissions of research conducted and published before 1980 [26, 27]. Our list may have missed some citation classics; this can be explained as 'obliteration by incorporation' [12], which in simple terms states that the content of some classic articles has become such common knowledge that they no longer require citation.

\section{Conclusions}

We conclude that the neurologic and analgesic aspects of opioids are well established in the top 100 citation classics. Endogenous and synthetic opioids were the most studied. Although addiction and misuse of opioids is a worldwide menace to health and economy, this concern 


\section{Cureus}

was underrepresented in the citation classics. We would also like to draw attention to the pulmonary and gastrointestinal aspects of opioids, which are marginalized among the citation classics. Similarly, quality papers on opium alkaloids, semi-synthetic opioids, and substance abuse are needed.

\section{Appendices}

\begin{tabular}{|c|c|c|c|c|}
\hline Rank & Title & Citation & $\begin{array}{l}\text { Citation } \\
\text { density }\end{array}$ & $\begin{array}{l}\text { Most } \\
\text { Cited } \\
\text { (Year) }\end{array}$ \\
\hline 1 & $\begin{array}{l}\text { Drugs abused by humans preferentially increase synaptic dopamine } \\
\text { concentrations in the mesolimbic system of freely moving rats. Proceedings of } \\
\text { the National Academy of Sciences, } 1988\end{array}$ & 3149 & 108.59 & 2014 \\
\hline 2 & $\begin{array}{l}\text { Identification of two related pentapeptides from the brain with potent opiate } \\
\text { agonist activity. Nature, } 1975\end{array}$ & 2677 & 63.74 & 1977 \\
\hline 3 & $\begin{array}{l}\text { The effects of morphine-and nalorphine-like drugs in the nondependent and } \\
\text { morphine-dependent chronic spinal dog. Journal of Pharmacology and } \\
\text { Experimental Therapeutics, } 1976\end{array}$ & 2336 & 56.98 & 1982 \\
\hline 4 & A psychomotor stimulant theory of addiction. Psychological Review, 1987 & 2077 & 69.23 & 1999 \\
\hline 5 & Endogenous opioid peptides: multiple agonists and receptors. Nature, 1977 & 1928 & 48.2 & 1982 \\
\hline 6 & $\begin{array}{l}\text { The formalin test: a quantitative study of the analgesic effects of morphine, } \\
\text { meperidine, and brain stem stimulation in rats and cats. Pain, } 1977\end{array}$ & 1843 & 46.08 & 2011 \\
\hline 7 & $\begin{array}{l}\text { A randomized, controlled trial of methylprednisolone or naloxone in the } \\
\text { treatment of acute spinal-cord injury: results of the Second National Acute } \\
\text { Spinal Cord Injury Study. The New England Journal of Medicine, } 1990\end{array}$ & 1820 & 67.41 & 2002 \\
\hline 8 & $\begin{array}{l}\text { Drugs of abuse: anatomy, pharmacology and function of reward pathways. } \\
\text { Trends in Pharmacological Sciences, } 1992\end{array}$ & 1729 & 69.16 & 1998 \\
\hline 9 & $\begin{array}{l}\text { Isolation and structure of the endogenous agonist of opioid receptor-like ORL1 } \\
\text { receptor. Nature, } 1995\end{array}$ & 1636 & 74.36 & 2000 \\
\hline 10 & Cellular and molecular mechanisms of drug dependence. Science, 1988 & 1606 & 55.38 & 2000 \\
\hline 11 & $\begin{array}{l}\text { A neuropeptide that activates an opioidlike G protein-coupled receptor. } \\
\text { Science, } 1995\end{array}$ & 1592 & 72.36 & 2000 \\
\hline 12 & $\begin{array}{l}\text { Intrathecal morphine in mice: a new technique. European Journal of } \\
\text { Pharmacology, } 1980\end{array}$ & 1433 & 38.73 & 2013 \\
\hline 13 & $\begin{array}{l}\text { The self-medication hypothesis of addictive disorders: focus on heroin and } \\
\text { cocaine dependence. In: The Cocaine Crisis: Springer; } 1987\end{array}$ & 1413 & 44.16 & $\begin{array}{l}2011- \\
2012\end{array}$ \\
\hline 14 & Opiate receptor: demonstration in nervous tissue. Science, 1973 & 1367 & 31.07 & 1981 \\
\hline 15 & $\begin{array}{l}\text { The formalin test in mice: dissociation between inflammatory and non- } \\
\text { inflammatory pain. Pain, } 1987\end{array}$ & 1355 & 45.17 & $2011 ; 2014$ \\
\hline
\end{tabular}




\section{Cureus}

16 insurance, and outcomes evaluation. Jama, 2000

Clinical guidelines for the use of chronic opioid therapy in chronic noncancer pain. The Journal of Pain, 2009

Loss of morphine-induced analgesia, reward effect and withdrawal symptoms

beta-Endorphin and adrenocorticotropin are selected concomitantly by the pituitary gland. Science, 1977

A potent and selective endogenous agonist for the mu-opiate receptor. Nature, 1997

Cloning of a delta opioid receptor by functional expression. Science, 1992

P-glycoprotein in the blood-brain barrier of mice influences the brain

Investigation, 1996

Opioids excite dopamine neurons by hyperpolarization of local interneurons.

Journal of Neuroscience, 1992

Chronic parkinsonism secondary to intravenous injection of meperidine analogues. Psychiatry Research, 1979

Inhibition of morphine tolerance and dependence by the NMDA receptor antagonist MK-801. Science, 1991

Bispectral analysis measures sedation and memory effects of propofol, 1997

Placebo and opioid analgesia--imaging a shared neuronal network. Science, 2002

Unresponsiveness to cannabinoids and reduced addictive effects of opiates in CB1 receptor knockout mice. Science, 1999

Opioid-receptor mRNA expression in the rat CNS: anatomical and functional implications. Trends in Neurosciences, 1995

Endogenous opioids: biology and function. Annual Review of Neuroscience, 1984

Common precursor to corticotropins and endorphins. Proceedings of the National Academy of Sciences, 1977

Heroin addicts have higher discount rates for delayed rewards than non-drugusing controls. Journal of Experimental Psychology: General, 1999

Dynorphin is a specific endogenous ligand of the kappa opioid receptor. Science, 1982

Opioid and nonopioid components independently contribute to the mechanism 


\section{Cureus}

England Journal of Medicine, 2005

Single-nucleotide polymorphism in the human mu opioid receptor gene alters expression and localization. FEBS letters, 1994

$\beta$-endorphin binding and activity: possible implications for opiate addiction.

Proceedings of the National Academy of Sciences, 1998

Stereospecific binding of the potent narcotic analgesic $[3 \mathrm{H}]$ etorphine to ratbrain homogenate. Proceedings of the National Academy of Sciences, 1973

Bis-penicillamine enkephalins possess highly improved specificity toward delta opioid receptors. Proceedings of the National Academy of Sciences, 1983

Cannabinoid and heroin activation of mesolimbic dopamine transmission by a common $\mu 1$ opioid receptor mechanism. Science, 1997

Autoradiographic differentiation of mu, delta, and kappa opioid receptors in the rat forebrain and midbrain. Journal of Neuroscience, 1987

U-50,488: a selective and structurally novel non-Mu (kappa) opioid agonist. Journal of Pharmacology and Experimental Therapeutics, 1983

Opposite effects of mu and kappa opiate agonists on dopamine release in the nucleus accumbens and in the dorsal caudate of freely moving rats. Journal of Pharmacology and Experimental Therapeutics, 1988

and Experimental Therapeutics, 1992

ORL1, a novel member of the opioid receptor family: cloning, functional

\begin{tabular}{|c|c|c|}
\hline 897 & 39 & 2000 \\
\hline 896 & 47.16 & 2006 \\
\hline 895 & 27.12 & 1989 \\
\hline 881 & 35.24 & 1994 \\
\hline 837 & 25.36 & 1989 \\
\hline 826 & 28.48 & 2003 \\
\hline 820 & 58.57 & 2009 \\
\hline 793 & 20.33 & 1984 \\
\hline 788 & 32.83 & 1996 \\
\hline 787 & 65.56 & 2011 \\
\hline
\end{tabular}




\section{Cureus}

Dissociable deficits in the decision-making cognition of chronic amphetamine abusers, opiate abusers, patients with focal damage to prefrontal cortex, and

tryptophan-depleted normal volunteers: evidence for monoaminergic mechanisms. Neuropsychopharmacology, 1999

Opioids in chronic non-cancer pain: systematic review of efficacy and safety.

Pain, 2004

Opposing tonically active endogenous opioid systems modulate the mesolimbic 1992

Opiate analgesics inhibit substance $\mathrm{P}$ release from rat trigeminal nucleus. Nature, 1977

Influence of age and gender on the pharmacokinetics and pharmacodynamics of remifentanil. Model Development. The Journal of the American Society of Anesthesiologists, 1997

Progressive ratio schedules in drug self-administration studies in rats: a 1996

The Severity of Dependence Scale (SDS): psychometric properties of the SDS in English and Australian samples of heroin, cocaine and amphetamine users. Addiction, 1995

Mechanisms of hyperalgesian and morphine tolerance: a current view of their possible interactions. Pain, 1995

The effects of psychosocial services in substance abuse treatment. Addictions Nursing Network, 1993

Morphine and alternative opioids in cancer pain: the EAPC recommendations.

A medical treatment for diacetylmorphine (heroin) addiction: a clinical trial with methadone hydrochloride. Jama, 1965

Tolerance of locus coeruleus neurones to morphine and suppression of withdrawal response by clonidine. Nature, 1978

Immunohistochemical localization of enkephalin in rat brain and spinal cord. Journal of Comparative Neurology, 1978

Autoradiographic localization of opiate receptors in rat brain. Spinal cord and lower medulla. Brain Research, 1977 Isolation of an endogenous compound from the brain with pharmacological properties similar to morphine. Brain Research, 1975

Opioid-induced hyperalgesia: a qualitative systematic review. The Journal of the American Society of Anesthesiologists, 2006

The action of morphine and related substances on contraction and on 


\section{Cureus}

71 acetylcholine output of coaxially stimulated guinea-pig ileum. British Journal of

Pharmacology, 1957

Acute opioid tolerance intraoperative remifentanil increases postoperative pain

Anesthesiologists, 2000

Intravenous cocaine, morphine, and amphetamine preferentially increase

A new method for receptor autoradiography: [3 $\mathrm{H}$ ] opioid receptors in rat brain. Brain Research, 1979

Organization of endogenous opiate and nonopiate pain control systems.

Science, 1982

Impulsivity as a vulnerability marker for substance-use disorders: review of findings from high-risk research, problem gamblers and genetic association studies. Neuroscience \& Biobehavioral Reviews, 2008

Neurobiology of relapse to heroin and cocaine seeking: a review.

Opioid and nonopioid mechanisms of stress analgesia. Science, 1980

Cellular and synaptic adaptations mediating opioid dependence. Physiological

Crystal structure of the [micro]-opioid receptor bound to a morphinan antagonist. Nature, 2012

The enkephalinase inhibitor thiorphan shows antinociceptive activity in mice.

Endorphins: profound behavioral effects in rats suggest new etiological factors in mental illness. Science, 1976

Halothane-morphine compared with high-dose sufentanil for anesthesia and postoperative analgesia in neonatal cardiac surgery. The New England Journal of Medicine, 1992

Control CfD, Prevention: Vital signs: overdoses of prescription opioid pain relievers - United States, 1999 - 2008. MMWR Morbidity and Mortality Weekly Report, 2011

Immunohistochemical studies using antibodies to leucine-enkephalin: initial observations on the nervous system of the rat. Neuroscience, 1976

The neostriatal mosaic: compartmentalization of corticostriatal input and striatonigral output systems. Nature, 1984

Cloning and sequence analysis of cDNA for porcine $\beta$-neoendorphin/dynorphin precursor. Nature, 1982 


\section{Cureus}

Pain relief by intrathecally applied morphine in man. Survey of Anesthesiology,

570 1979

Addictive drugs and brain stimulation reward. Annual Review of Neuroscience, 1996

Self-administration of psychoactive substances by the monkey.

Psychopharmacology, 1969

Efficacy of oxycodone in neuronathic pain: a randomized trial in postherpetic neuralgia. Neurology, 1998

Multiple opiate receptors. Enkephalins and morphine bind to receptors of different specificity. Journal of Biological Chemistry, 1979

International Union of Pharmacology. XII. Classification of opioid receptors. Pharmacological Reviews, 1996

Cloning and functional comparison of kappa and delta opioid receptors from mouse brain. Proceedings of the National Academy of Sciences, 1993

$\mathrm{Mu}$, delta, and kappa opioid receptor mRNA expression in the rat CNS: an in situ hybridization study. Journal of Comparative Neurology, 1994

Intrathecal morphine inhibits substance $\mathrm{P}$ release from mammalian spinal cord in vivo. Nature, 1980

Neurobiological similarities in depression and drug dependence: a selfmedication hypothesis. Neuropsychopharmacology, 1998

\section{TABLE 3: Top 100 Articles on opioids.}

CNS - Central Nervous System

NMDA receptor - N-methyl-D-aspartate receptor

COMT - Catechol-O-methyltransferase

EAPC - European Association for Palliative Care

\section{Additional Information}

\section{Disclosures}

Human subjects: All authors have confirmed that this study did not involve human participants or tissue. Animal subjects: All authors have confirmed that this study did not involve animal subjects or tissue. Conflicts of interest: In compliance with the ICMJE uniform disclosure form, all authors declare the following: Payment/services info: All authors have declared that no financial support was received from any organization for the submitted work. Financial relationships: All authors have declared that they have no financial relationships at present or within the previous three years with any organizations that might have an interest in 
the submitted work. Other relationships: All authors have declared that there are no other relationships or activities that could appear to have influenced the submitted work.

\section{References}

1. Regehr G: Trends in medical education research. Acad Med. 2004, 79:939-947.

2. Ellegaard O, Wallin JA: The bibliometric analysis of scholarly production: how great is the impact?. Scientometrics. 2015, 105:1809-1831. 10.1007/s11192-015-1645-z

3. Glynn RW, Scutaru C, Kerin MJ, Sweeny KJ: Breast cancer research output, 1945-2008: a bibliometric and density-equalizing analysis. Breast Cancer Res. 2010, 12:108. 10.1186/bcr2795

4. Kelly J, Glynn R, O'Briain D, McCabe JP: The 100 classic papers of orthopaedic surgery: a bibliometric analysis. J Bone Joint Surg Br. 2010, 92:1338-1343. 10.1302/0301620X.92B10.24867

5. Ibrahim GM, Carter Snead O, Rutka JT, Lozano AM: The most cited works in epilepsy: trends in the "citation classics". Epilepsia. 2012, 53:765-770. 10.1111/j.1528-1167.2012.03455.x

6. Siddiqi TJ, Usman MS, Khan MS, et al.: The 100 most influential papers in the field of thrombolytic therapy: a bibliometric analysis. Am J Cardiovasc Drugs. 2017, 17:319-333. 10.1007/s40256-017-0227-2

7. Usman MS, Siddiqi TJ, Khan MS, Fatima K, Butler J, Manning WJ, Khosa F: A scientific analysis of the 100 citation classics of valvular heart disease. Am J Cardiol. 2017, 120:1440-1449. 10.1016/j.amjcard.2017.07.035

8. Manglik A, Kruse AC, Kobilka TS, et al.: Crystal structure of the [micro]-opioid receptor bound to a morphinan antagonist. Nature. 2012, 485:321-326. 10.1038/nature10954

9. Brunton LL, Chabner BA, Knollman BC : Goodman and Gilman's: The Pharmacological Basis of Therapeutics. Mc Graw-Hill Education, New York ; 2011.

10. "Opioids." National Institute on Drug Abuse. Accessed: October 29, 2017 : https://www.drugabuse.gov/drugs-abuse/opioids.

11. Benyamin R, Trescot A, Datta S, et al.: Opioid complications and side effects . Pain Physician J. 2008, 11:S105-120.

12. Garfield E: 100 citation classics from the journal of the american medical association . JAMA. 1987, 257:52-59. 10.1001/jama.1987.03390010056028

13. Falagas ME, Pitsouni EI, Malietzis GA, Paappas G: Comparison of pubMed, scopus, web of science, and google scholar: strengths and weaknesses. FASEB J. 2008, 2:338-342. 10.1096/fj.07-9492LSF

14. Schumacher MA, Basbaum AI, Way WL: Opioid Analgesics \& Antagonists. Basic and Clinical Pharmacology. Mc Graw-Hill Education, New York; 2012. 543-564.

15. Zijlstra H, McCullough R: CiteScore: a new metric to help you track journal performance and make decisions. Elsevier. 2016, Accessed: October 29, 2017: https://www.elsevier.com/editors-update/story/journal-metrics/citescore-a-new-metric-tohelp-you-choose-the-right-jou....

16. Pathan H, Williams J: Basic opioid pharmacology: an update. Br J Pain. 2012, 6:11-16. 10.1177/2049463712438493

17. Duarte DF: Opium and opioids: a brief history (in Spanish). Rev Bras Anestesiol. 2005, 55:135146. 10.1590/S0034-70942005000100015

18. Paladugu R, Schein M, Gardezi S, Wise L: One hundred citation classics in general surgical journals. World J Surg. 2002, 26:1099-1105. 10.1007/s00268-002-6376-7

19. Campbell FM: National bias: a comparison of citation practices by health professionals . Bull Med Libr Assoc. 1990, 78:376-382.

20. Stossel TP: Volume: papers and academic promotion. Ann Intern Med. 1987, 106:146-149. 10.7326/0003-4819-106-1-146

21. Nash-Stewart CE: Does Bradford's law of scattering predict the size of the literature in cochrane reviews?. J Med Libr Assoc. 2012, 100:135-138. 10.3163/1536-5050.100.2.013

22. La Torre G, Sciarra I, Chiappetta M, Monteduro A: New bibliometric indicators for the scientific literature: an evolving panorama. Clin Ter. 2017, 168:65-71.

23. Flam F: Neuroscience Offers Insights Into the Opioid Epidemic . Bloomberg View. 2017, Accessed: October 29, 2017: https://www.bloomberg.com/view/articles/2017-0721/neuroscience-offers-insights-into-the-opioid-epidemic. 


\section{Cureus}

24. Camilleri M, Lembo A, Katzka DA: Opioids in Gastroenterology: Treating Adverse Effects and Creating Therapeutic Benefits. Clin Gastroenterol. Hepatol, 2017:1338-1349.

10.1016/j.cgh.2017.05.014

25. American society of addiction medicine: opioid addiction 2016 facts and figures . (2016). Accessed: October 29, 2017: https://www.asam.org/docs/default-source/advocacy/opioidaddiction-disease-facts-figures.pdf.

26. Brandt JS, Downing AC, Howard DL, Kofinas JD, Chasen ST: Citation classics in obstetrics and gynecology: the 100 most frequently cited journal articles in the last 50 years. Am J Obstet Gynecol. 2010, 203:355-1. 10.1016/j.ajog.2010.07.025

27. Bakkalbasi N, Bauer K, Glover J, Wang L: Three options for citation tracking: google scholar, scopus and web of science. Biomed Digit Libr. 2006, 3:7. 10.1186/1742-5581-3-7 